\title{
Election results
}

\author{
Vanessa Cameron
}

The results of the recent election of President are as follows:

Number of ballot papers distributed 8032

Number of ballot papers returned $\quad 3040$

Number of invalid ballot papers 1

Number of valid ballot papers counted 3039 (38\%)

\section{First stage}

John Cox

David Goldberg

John Gunn
1090

1085

864

\section{Second stage}

John Cox

David Goldberg

John Gunn

(non-transferable

1505

1404

130)

Professor John Cox is therefore elected as President and will take Office from 1 July 1999

Vanessa Cameron. The Secretary, Royal College of Psychiatrists, 17 Belgrave Square, London SWIX 8PG

\section{Annual elections}

\section{Council and Court of Electors}

Fellows and Members of the College are reminded of their rights in connection with the forthcoming elections for the vacancies on the Court of Electors and for Elected Members of Council. The relevant Bye-Laws and Regulations are printed below.

The nominating meeting of Council will be held on 29 April 1999 and the last date for receiving nominations will therefore be 27 May 1999.

Extracts from Bye-Laws and Regulations Bye-Law XXI THE COURT OF ELECTORS

4. At the first meeting of the Council in alternate years after the name of the President for the next ensuing College year has become known, the Council shall nominate a sufficient number of candidates for appointment as Electors to ensure an election, which will be held by a postal ballot of all Members of the College in the manner prescribed by the Regulations. Additional nominations may be lodged with the Registrar between the beginning of the then current calendar year and the end of four clear weeks after the meeting of the Council above referred to. No such nomination shall be valid unless it is supported in writing by twelve Members of the College and accompanied by the nominee's written consent to serve if elected.

\section{Regulation XIX THE couNCIL}

2. Not less than two of the six elected Members of the Council and the two of the six elected Fellows shall be elected or re-elected each alternate year subject to the overall condition that no elected member shall serve on Council for more than six years in that capacity without a break of at least one year. At its first meeting in each alternate College year after the name of the President for the next ensuing College year has become known, the Council shall nominate for election to the Council two Members and two Fellows of the College. Any nominee who is proposed and seconded and gives his or her consent in writing to serve shall be validly nominated. Any twelve Members of the College may make nominations in writing at any time between the first day of January in each 